\title{
APLIKASI BEBERAPA JENIS PUPUK ORGANIK PADA PERTUMBUHAN DAN PRODUKSI PADI SAWAH METODE SRI (System of Rice Intensification)
}

\section{APPLICATION OF SOME TYPE OF ORGANIC FERTILIZERS ON GROWTH AND YIELD OF RICE IN SRI (System of Rice Intensification) METHOD}

Jeanne M. Paulus ${ }^{1)}$ dan Jein H. Senduk ${ }^{2)}$

1)Dosen Fakultas Pertanian Universitas Sam Ratulangi Manado, 95115

2)Staf Balai Pengawasan dan Sertifikasi Benih Sulut

e-mail : jeanne.paulus@yahoo.co.id

\begin{abstract}
The aim of the research was to studied the growth and production of rice with SRI methods as a response to application some type of organic fertilizer. The field experiment was conducted in Tara Tara Village, Tomohon North Sulawesi for 5 months. The research arranged in Randomized Block Design with the treatmentof several types of organic fertilizers (PO) : without PO+100\% NPK (P0), PO market waste $+40 \%$ NPK $(P 1)$, PO legum $(P 2)+40 \%$ NPK, PO rice straw $(P 3)+40 \% N P K$, and $P O$ mix $+40 \%$ NPK (P4). The result showed that application of some type of organic fertilizer were significant effect to plant height, number of tillers, number of grains per panicle, 1000 grain weight, and grain yield, except percentage pithy grain per panicle. The highest of grain yield achieved by the treatment of PO rice straw $+40 \%$ NPK and PO legum $+40 \%$ NPK, i.e 9,03 tha-1 and 8,62 ton ha- ${ }^{-1}$
\end{abstract}

Key words : organic fertilizer, rice, SRI (System of Rice Intensification)

\begin{abstract}
ABSTRAK
Penelitian ini bertujuan untuk mempelajari pertumbuhan dan produksi padi sawah metode SRI (System of Rice Intensification) sebagai respon terhadap aplikasi beberapa jenis pupuk organik. Penelitian lapangan telah dilaksanakan di Desa Tara-Tara Kota Tomohon, Sulawesi Utara selama 5 bulan. Penelitian disusun dalam Rancangan Acak Kelompok dengan perlakuan beberapa jenis pupuk organik (PO) : tanpa PO +100\% NPK (P0), PO sampah pasar + 40\% NPK (P1), PO tanaman legum (P2) + $40 \%$ NPK, PO jerami (P3) + 40\% NPK, dan PO campuran + 40\% NPK (P4). Hasil penelitian menunjukkan bahwa pemberian pupuk organik berpengaruh nyata terhadap tinggi tanaman, jumlah anakan, jumlah gabah per malai, bobot 1000 butir, dan hasil gabah kering panen (GKP); kecuali prosentase gabah bernas per malai. Hasil GKP tertinggi dicapai oleh perlakuan pupuk organik jerami dan pupuk organik tanaman legum yang dikombinasikan dengan $40 \% \mathrm{NPK}$, yaitu masing-masing $9,03 \mathrm{t}$ ha-1 dan 8,62 ton ha-1.

Kata kunci : pupuk organik, padi sawah, SRI (System of Rice Intensification)
\end{abstract}




\section{PENDAHULUAN}

Usaha intensifikasi padi melalui program Revolusi Hijau telah mampu mengantarkan Indonesia berswasembada beras selama 30 tahun, namun pada akhirnya menimbulkan dampak negatif dari penggunaan pupuk dan pestisida kimia pada dosis tinggi dan waktu yang panjang, antara lain terjadi penurunan kesuburan tanah sehingga penambahan input tidak mampu lagi memacu kenaikan produktivitas padi, rendahnya kelenturan sistem usaha tani karena penggunaan input kimia yang tinggi, dan mengabaikan kelestarian sumber daya lahan dan lingkungan serta sumber daya lokal.

Revolusi Hijau dengan berbagai dampaknya sudah harus ditinggalkan dan diarahkan pada program Revolusi Hijau Lestari. Gerakan usaha tani tersebut berbasis padi dengan memperhatikan keanekaragaman potensi sumber daya pertanian (lahan/tanah, air iklim), kearifan lokal, dan teknologi indigenous (pupuk/bahan organik, dan lain-lain), pembangunan pertanian berkelanjutan dengan memanfaatkan IPTEK tinggi yang adaptif dan ramah lingkungan, berupa inovasi teknologi Varietas Unggul Baru (VUB), komponen teknologi pengelolaan LATO (lahan, air, tanah dan organisme pengganggu), dan sistem farming dengan perhatian yang lebih besar terhadap upaya peningkatan pendapatan petani (Las, 2009).

Salah satu pendekatan yang dapat menunjang program Revolusi Hijau Lestari adalah System of Rice Intensification (SRI). SRI merupakan salah satu teknologi produksi untuk meningkatkan produktivitas tanaman padi. Menurut Prof. Norman Uphoff dalam Anonim (2009) bahwa metode SRI merupakan sebuah konsep agroekologi yang mengedepankan pengaturan terhadap tanaman, tanah, air, dan pupuk. Pengertian yang sama dikemukakan oleh Anugrah, Sumedi, dan Wardhana, (2008), bahwa metode SRI merupakan salah satu pendekatan dalam praktek budidaya padi yang menekankan pada manajemen pengelolaan tanah, tanaman, dan air melalui pemberdayaan kelompok dan kearifan lokal yang berbasis pada kegiatan ramah lingkungan.
Badan Penelitian Tanaman Padi di Sukamandi, Jawa Barat pada tahun 1999 telah melaksanakan pengujian dan evaluasi SRI. Hasil pengujian menunjukkan bahwa produksi padi dengan metode SRI sebesar 6.2 t/ha sedangkan hasil dari petak kontrolnya $4.1 \mathrm{t} / \mathrm{ha}$, sehingga terjadi peningkatan hasil sebesar 66,12 \%. Metode SRI berkembang pesat di sejumlah daerah di pulau Jawa, bahkan di luar pulau Jawa, seperti Sumatera, Nusa Tenggara Timur, Nusa Tenggara Barat, dan Bali. Budidaya padi dengan metode SRI mempunyai beberapa keunggulan dibandingkan dengan metode konvensional, yaitu : (1) hemat air, selama pertumbuhan dari mulai tanam sampai panen pemberian air maksimum $2 \mathrm{~cm}$ paling baik macakmacak dan ada periode pengeringan sampai tanah retak, sehingga cocok diterapkan pada lahan dengan ketersediaan air rendah; (2) hemat benih karena metode ini mampu menghemat penggunaan benih padi sampai $80 \%$ atau hanya membutuhkan benih 8-10 kg/ha, sedangkan budidaya konvensional memerlukan benih sekitar $50 \mathrm{~kg}$; (3) hemat waktu karena penanaman bibit pada usia muda, yaitu 10 - 12 hari setelah semai, dan waktu panen akan lebih awal; (4) produksi meningkat disebabkan lebih banyak batang yang muncul dalam satu rumpun, sehingga lebih banyak bulir padi yang dihasilkan oleh malai; dan (5) ramah lingkungan karena secara bertahap mengurangi penggunaan pupuk kimia (urea, SP-36, KCl) dan menggantikannya dengan pupuk organik (kompos, pupuk kandang, pupuk cair), dan juga menggunakan pestisida organik (Dinas Pertanian Tanaman Pangan, 2006; Sampoerna, 2009).

Di Sulawesi Utara, budidaya padi organik khususnya dengan metode SRI belum diterapkan karena berbagai kendala, antara lain ketersediaan pupuk organik secara berkesinambungan belum terpenuhi, dan petani belum memahami untuk menghasilkan produk pertanian yang sehat dan aman bagi konsumen. Di pihak lain tuntutan untuk menerapkan budidaya organik sudah sangat mendesak mengingat konsumen mulai menyadari untuk mengkonsumsi bahan pangan yang sehat. Selain itu juga telah menjadi kebiasaan petani bahwa pada saat musim panen padi, limbah pertanaman seperti jerami dan sisa-sisa panen lainnya disingkirkan dari 
lahan sawah dengan cara dibakar sehingga sejumlah besar $\mathrm{N}, \mathrm{P}, \mathrm{K}$ dan unsur hara lainnya hanya terbuang begitu saja. Untuk dapat memanfaatkan limbah pertanaman tersebut diperlukan cara pengolahan jerami menjadi pupuk organik yang bermanfaat untuk meningkatkan produktivitas lahan sawah yang telah mengalami penurunan kesuburan tanah akibat aplikasi pupuk kimia dosis tinggi dan dalam jangka waktu yang lama.

Penelitian ini bertujuan untuk mempelajari karakteristik pertumbuhan dan produksi padi sawah sebagai respon terhadap aplikasi beberapa jenis pupuk organik. Diharapkan penelitian ini dapat memberikan manfaat kepada petani untuk memanfaatkan limbah organik sisa pertanaman sebagai bahan baku pembuatan pupuk organik pada sistem budidaya padi dengan metode SRI, juga kepada pengambil kebijakan untuk menghasilkan kebijakan-kebijakan dalam kegiatan penerapan budidaya padi SRI untuk menunjang ketahanan dan keamanan pangan di Provinsi Sulawesi Utara.

\section{METODE PENELITIAN}

Penelitian lapangan telah dilaksanakan di Desa Tara-Tara Kecamatan Tomohon Barat, Kota Tomohon Sulawesi Utara, selama 5 (lima) bulan, mulai dari April 2013 sampai dengan September 2013.

Bahan dan alat utama yang digunakan adalah : benih padi var. Sidenuk, pupuk organik, pupuk anorganik (urea, phonska $15: 15: 15$ ), pestisida nabati, dan timbangan analitis. Pupuk organik yang digunakan (sampah pasar, tanaman legum, dan jerami) berasal dari produk yang dibuat sendiri dengan cara pengomposan selama 3-4 minggu.

\section{Rancangan Percobaan}

Perlakuan disusun dalam Rancangan Acak Kelompok (RAK) dengan satu faktor perlakuan. Perlakuan tersebut adalah jenis pupuk organik $(\mathrm{PO})$, terdiri atas : $\mathrm{PO}=$ tanpa pupuk organik + $100 \%$ NPK, P1 = PO sampah pasar $+40 \%$ NPK, $\mathrm{P} 2=\mathrm{PO}$ tanaman legum $+40 \% \mathrm{NPK}, \mathrm{P} 3=\mathrm{PO}$ jerami, dan $\mathrm{P} 4=\mathrm{PO}$ bahan campuran dari $\mathrm{PO}$ sampah pasar : PO tanaman legum : PO jerami (1 :
$1: 1)+40 \%$ NPK. Setiap perlakuan diulang tiga kali.

\section{Pelaksanaan Percobaan}

Pembuatan pupuk organik (kompos) : jerami padi di cacah dengan ukuran $5-10 \mathrm{~cm}$, dicampur dengan dedak kemudian disiram dengan larutan EM4 yang dan larutan molase (campuran gula merah dan air). Pencampuran bahan-bahan tersebut dilakukan secara merata, dan setelah itu ditutup dengan terpal plastik. Pengontrolan suhu dilakukan setiap 3 hari sekali dengan membuka tutup beberapa saat dan sesudah itu terpal ditutp kembali. Proses fermentasi akan berlangsung sekitar 4 minggu, jerami telah berubah menjadi kompos dengan warna kecoklatan dan ditumbuhi cendawan berwarna putih. Demikian halnya dengan pembuatan kompos dari tanaman legum dan sampah pasar, bedanya kedua bahan ini dibiarkan beberapa hari untuk mengurangi kadar airnya baru dilakukan pembuatan kompos seperti pada bahan jerami.

Pengolahan tanah dengan dibajak sedalam 25 - $30 \mathrm{~cm}$ sambil membenamkan sisa-sisa tanaman dan rumput-rumputan sekaligus dilakukan aplikasi pupuk organik/kompos yang disebar secara merata dengan dosis 10 ton/ha. Analisis tanah pra percobaan telah dilakukan sebelum pengolahan tanah.

Persiapan dan persemaian benih dilakukan dengan memasukkan benih padi yang akan diuji ke dalam ember berisi larutan garam kemudian diaduk, pisahkan benih yang mengambang dengan yang tenggelam. Benih yang bermutu dicuci dengan air sampai bersih kemudian direndam selama 24 - 48 jam, diangkat dan dimasukkan ke dalam karung berpori, disimpan di tempat yang lembab.dan dianginkan selama 24 jam (Veco Indonesia, 2007)

Persemaian dilakukan dengan memyemai benih pada wadah plastik dengan media tanam campuran tanah, pasir dan pupuk organik dengan perbandingan 1:1:1.

Petak-petak percobaan dibuat dengan ukuran $3 \mathrm{~m} \times 4 \mathrm{~m}$, bibit ditanam dengan jarak tanam $35 \mathrm{~cm} \times 35 \mathrm{~cm}$. Penanaman dilakukan dengan langkah-langkah sebagai berikut : bibit dipindahkan 
ke lahan sawah pada umur11 hari setelah semai, biibit padi ditanam tunggal atau satu bibit per lubang pada kedalaman $1-1,5 \mathrm{~cm}$, akar tanaman berbentuk huruf $\mathrm{L}$ (horizontal) dengan kondisi tanah sawah macak-macak.

Pemberian pupuk organik sesuai dengan perlakuan dilakukan pada saat pengolahan tanah, pemupukan urea dengan dosis $150 \mathrm{~kg}^{\mathrm{k}}$ urea ha- ${ }^{-1}$ ( $40 \%$ dari dosis anjuran) dilakukan dua kali yaitu $1 / 2$ dosis pada saat tanam dan $1 / 2$ dosis pada saat tanaman memasuki fase primordia berbunga. Pupuk NPK Ponska $15: 15: 15$ diberikan satu kali yaitu pada saat tanam dengan dosis $200 \mathrm{~kg} \mathrm{NPK}$ ha $^{-1}$ ( $40 \%$ dari dosis anjuran)

Pemeliharaan tanaman, meliputi : pengendalian hama dan penyakit secara terpadu, penyiangan, dan pengelolaan air. Pemberian air, dengan cara terputus-putus (intermitten) dengan ketinggian air di petakan sawah maksimum $2 \mathrm{~cm}$, paling baik macak-macak $(0,5 \mathrm{~cm})$. Pada periode tertentu petakan sawah dikeringkan sampai pecahpecah.

Panen dilakukan pada saat bulir sudah menguning secara merata atau kadar air gabah sekitar 23-25\%.

Variabel respon yang diamati, meliputi : tinggi tanaman pada $7 \mathrm{MST}$, jumlah anakan pada umur $7 \mathrm{MST}$, jumlah gabah/malai, prosentase gabah bernas/malai, bobot 1000 butir gabah kering, dan hasil gabah kering panen/ha

\section{Analisis Data}

Data dari semua variabel pengamatan dianalisis dengan analisis sidik ragam (ANOVA) dan jika terdapat perbedaan dilanjutkan dengan Uji Beda Nyata Terkecil (BNT) pada taraf uji $5 \%$.

\section{HASIL DAN PEMBAHASAN}

\section{Keadaan Umum Percobaan}

Keadaan tanah sebelum percobaan dilaksanakan, adalah C-organik tergolong rendah, kandungan nitrogen rendah, $\mathrm{P}$ tersedia rendah, dan $\mathrm{K}$ tersedia sedang (Tabel 1). Kandungan unsur hara yang rendah pada tanah di lokasi percobaan diduga karena lahan tersebut belum pernah diaplikasikan dengan pupuk organik (kompos).

Keadaan pertanaman selama percobaan berlaangsung umumnya tidak terdapat serangan hama dan penyakit yang berarti, sehingga tidak dilakukan pengendalian hama dan penyakit secara kimiawi atau menggunakan pestisida akan tetapi hanya secara manual (fisik). Pada saat mendekati masa panen terdeteksi adanya serangan jamur berwarna kuning, namun prosentase serangan hanya sekitar $2 \%$. Pertumbuhan gulma cukup pesat karena kondisi sawah tidak tergenang air, sehingga penyiangan dilakukan sebanyak 4 kali pada saat tanaman berumur $10,20,30$, dan 40 HST dengan cara mencabut gulma yang ada disekitar pertanaman.

\section{Pertumbuhan dan Hasil Tanaman Padi \\ Hasil analisis statistik menunjukkan} bahwa, jenis pupuk organik berpengaruh terhadap tinggi tanaman umur 7 minggu setelah tanam (MST), jumlah anakan umur 7 MST, jumlah gabah per malai, bobot 1000 butir GKG, dan hasil GKP, namun tidak berpengaruh terhadap bobot 1000 butir GKG (Tabel 2).

Tabel 1. Hasil Analisis Tanah Sebelum Percobaan

(Table 1. Soil Analisys Pre-Research)

\begin{tabular}{lcl}
\hline \multicolumn{1}{c}{ Unsur } & Nilai & Kriteria \\
\hline C-Organik & $1,59 \%$ & Rendah \\
Nitrogen (N) & $0,14 \%$ & Rendah \\
$\mathrm{P}_{2} \mathrm{O}_{5}$ (P-tersedia) & $6 \mathrm{ppm}$ & Rendah \\
$\mathrm{K}_{2} \mathrm{O}$ (K-tersedia) & $27,62 \mathrm{ppm}$ & Sedang \\
\hline
\end{tabular}

Sumber : Laboratorium Jurusan Tanah, Fakultas Pertanian Unsrat (2013) 
Tabel 2. Aplikasi Jenis Pupuk Organik Terhadap Tinggi Tanaman Umur 7 MST, Jumlah Anakan umur 7 MST, Jumlah Gabah per Malai, Prosentase Gabah Bernas, Bobot 1000 Butir GKG, dan Hasil GKP

(Table 2. Application of Some Types of Organic Fertilizers on Plant Height 7 MST, Number of Tillers, Number of Grains per Panicle, Procentage of Pithy Grain per Panicle, 1000 Grain Weight and Grain Yield)

\begin{tabular}{|c|c|c|c|c|c|c|}
\hline Perlakuan & $\begin{array}{l}\text { Tinggi } \\
\text { Tanaman } \\
(\mathrm{cm})\end{array}$ & $\begin{array}{l}\text { Jumlah } \\
\text { Anakan }\end{array}$ & $\begin{array}{l}\text { Jumlah } \\
\text { Gabah/ } \\
\text { Malai }\end{array}$ & $\begin{array}{c}\% \text { Gabah } \\
\text { Bernas / } \\
\text { Malai }\end{array}$ & $\begin{array}{c}\text { Bobot } 1000 \\
\text { Butir GKG } \\
\text { (g) }\end{array}$ & $\begin{array}{l}\text { Hasil GKP } \\
\qquad\left(\mathrm{t} \mathrm{ha}^{-1}\right)\end{array}$ \\
\hline Tanpa PO + 100\% NPK & $99,60 \mathrm{~b}$ & $17,87 d$ & $238,70 \mathrm{ab}$ & $95,67 a$ & $28,96 a b$ & $8,25 \mathrm{bc}$ \\
\hline $\begin{array}{l}\text { PO sampah pasar + } \\
40 \% \text { NPK }\end{array}$ & 104,33 a & $21,87 \mathrm{c}$ & $225,97 \mathrm{~b}$ & $95,93 \mathrm{a}$ & $29,71 \mathrm{a}$ & $7,96 \mathrm{c}$ \\
\hline $\begin{array}{l}\text { PO tanaman legum + } \\
40 \% \mathrm{NPK}\end{array}$ & $101,67 a b$ & $26,00 \mathrm{~b}$ & $242,03 a b$ & 95,07 a & $29,25 a b$ & $8,62 \mathrm{ab}$ \\
\hline PO jerami + 40\% NPK & 103,27 a & $30,60 \mathrm{a}$ & $248,93 a$ & $96,03 \mathrm{a}$ & $28,57 \mathrm{~b}$ & $9,03 a$ \\
\hline $\begin{array}{l}\text { PO campuran + 40\% } \\
\text { NPK }\end{array}$ & $102,47 a b$ & $21,60 \mathrm{c}$ & $233,20 a b$ & 94,87 a & $28,64 \mathrm{~b}$ & $8,29 \mathrm{bc}$ \\
\hline BNT $5 \%$ & 3,48 & 2,64 & 11,49 & - & 0,92 & 0,51 \\
\hline
\end{tabular}

Ket : Angka-angka yang diikuti huruf yang sama pada kolom yang sama tidak berbeda menurut uji BNT 5\%

Berdasarkan jenis pupuk organik, tinggi tanaman tertinggi dicapai berturut-turut oleh perlakuan PO sampah pasar + $40 \%$ NPK, PO jerami + $40 \%$ NPK, PO campuran $+40 \%$ NPK, dan PO tanaman legum $+40 \%$ NPK dan PO campuran + $40 \%$ NPK, dengan nilai masing-masing $104,33 \mathrm{~cm}$; $103,27 \mathrm{~cm} ; 102,47 \mathrm{~cm}$; dan 101,67 cm. Sedangkan terendah dicapai oleh perlakuan kontrol (tanpa $\mathrm{PO}+100 \% \mathrm{NPK}$ ) dengan nilai $99,60 \mathrm{~cm}$.

Jumlah anakan tertinggi dicapai oleh perlakuan PO jerami $+40 \%$ NPK dengan nilai 30,60 anakan, diikuti oleh PO tanaman legum $+40 \% \mathrm{NPK}$ 26,00 anakan, PO sampah pasar $+40 \%$ NPK dan PO campuran, masing-masing 21,87 dan 21,60 anakan. Nilai terendah olehperlakuan tanpa PO + 100\% NPK yaitu 17,87 anakan.

Jumlah gabah per malai tertinggi dicapai berturut-turut oleh, PO jerami $+40 \%$ NPK, PO campuran $+40 \%$ NPK, dan PO tanaman legum + $40 \%$ NPK, tanpa PO + $100 \%$ NPK dan PO campuran $+40 \% \mathrm{NPK}$, dengan nilai masing-masing 248,$93 ; 242,03 ; 238,70 ;$ dan 233,20 . Sedangkan terendah dicapai oleh perlakuan PO sampah pasar $+40 \%$ NPK dengan nilai 225,97.

Bobot 1000 butir GKG tertinggi dicapai berturut-turut oleh perlakuan $\mathrm{PO}$ sampah pasar + $40 \%$ NPK, PO tanaman legum $+40 \%$ NPK, dan tanpa $\mathrm{PO}+100 \% \mathrm{NPK}$, dengan nilai masingmasing $29,71 \mathrm{~g} ; 29,25 \mathrm{~g} ; 28,96 \mathrm{~g}$.
Hasil GKP tertinggi dicapai oleh perlakuan PO jerami $+40 \%$ NPK dan PO tanaman legum + $40 \%$ NPK dengan nilai masing-masing 9,03 dan 8,62 t ha- $^{-1}$, diikuti dengan PO campuran $+40 \% \mathrm{NPK}$ dan tanpa PO $+100 \%$ NPK sebesar 8,29 dan $8,25 \mathrm{t} \mathrm{ha}^{-1}$, dan terendah pada perlakuan $\mathrm{PO}$ sampah pasar $+40 \%$ NPK dengan nilai $7,96 \mathrm{t} \mathrm{ha}^{-1}$

Tinggi tanaman dengan nilai yang tinggi pada perlakuan semua jenis pupuk organik baik $\mathrm{PO}$ jerami, PO tanaman legum, PO sampah pasar, dan PO campuran, menunjukkan bahwa pemberian pupuk organik dapat memperbaiki kesuburan tanah baik kondisi fisik, kimia, dan biologi tanah sehingga berpengaruh positif pada pertumbuhan vegetatif tanaman. Menurut Sutanto (2002) bahwa penggunaan pupuk organik dapat memperbaiki sifat fisik tanah yaitu tanah menjadi gembur dan warna tanah berubah dari warna cerah menjadi warna kelam; memperbaiki sifat kimia tanah yaitu meningkatkan kapasitas tukar kation sehingga ketersediaan hara meningkat; memperbaiki sifat biologi tanah dengan mempercepat perkembangan mikroorganisme; dan juga mempengaruhi kondisi sosial masyarakat yaitu dapat mengurangi pencemaran lingkungan dan meningkatkan lapangan kerja pada daur ulang limbah untuk penyediaan pupuk organik. Hal yang sama dilaporkan oleh Nizar (2011) dalam hasil percobaannya bahwa bahan organik sampah kota, kotoran ayam, thitonia, dan jerami padi memberikan 
pengaruh positif yang sama terhadap pertumbuhan dan hasil tanaman padi metode SRI. Pengaruh terbaik terhadap jumlah anakan pada minggu ke-8 adalah thitonia jika dibandingkan dengan sampah kota, kotoran ayam, dan jerami padi.

Perlakuan PO jerami memberikan nilai jumlah anakan tertinggi, hal tersebut sesuai dengan hasil penelitian Ningtias dan Suharjanto (2012), bahwa pemanfaatan jerami padi pada penerapan System Intensifikasi Padi Aerob Terkendali Berbasis Organik (IPAT-BO) dapat memperbaiki kesuburan tanah dengan meningkatkan pertumbuhan tanaman misalnya tinggi tanaman, jumlah anakan, dan hasil panen sebesar 9,10 ton/ha. Demikian juga dilaporkan oleh Kaya (2013), bahwa pemberian kompos jerami bersama-sama dengan pupuk NPK dapat meningkatkan serapan N, tinggi tanaman, dan jumlah anakan. Pemberian kompos jerami dengan dosis 3 ton/ha bersama-sama dengan pupuk NPK $150 \mathrm{~kg} / \mathrm{ha}$ memberikan serapan N tertinggi sebesar $3,51 \%$.

Hasil gabah kering panen tertinggi $(9,03$ ton ha-1) pada perlakuan $\mathrm{PO}$ jerami $+40 \%$ NPK dan 8,62 ton ha-1 pada perlakuan PO legum $+40 \%$ NPK, ditunjang oleh pertumbuhan dan komponen hasil tanaman padi, seperti tinggi tanaman, jumlah anakan, dan jumlah gabah per malai, sehingga menghasilkan produksi atau hasil gabah kering panen yang tertinggi dibandingkan dengan jenis $\mathrm{PO}$ lainnya. Hasil yang sama dilaporkan oleh Paulus, Rogi dan Senduk (2014) pada sistem budidaya padi konvensional (non SRI), bahwa perlakuan PO gamal dan $\mathrm{PO}$ jerami yang dikombinasikan dengan $50 \%$ NPK menghasilkan gabah kering panen tertinggi, yaitu masing-masing $41,63 \mathrm{~kg}$ dan $38,67 \mathrm{~kg}$. Hasil tertinggi yang dicapai tersebut, disebabkan oleh kandungan nitrogen yang cukup tinggi pada pada kompos jerami dan kompos tanaman legum (kaliandra). Menurut Mulyadi (2008), bahwa pada kompos jerami mengandung $\mathrm{NH}_{4}^{+}$dan $\mathrm{NO}_{3}^{-}$ masing-masing sebesar 234 ppm dan 7688 ppm, kompos kaliandra 144 ppm dan 7750 ppm, sedangkan kompos sayuran sebesar 252 ppm dan 2170 ppm.

Peningkatan hasil tanaman padi sebagai respon terhadap pemberian kombinasi kompos dan pupuk anorganik dilaporkan oleh Barus (2011), bahwa perlakuan kombinasi pupuk kompos dan NPK $75 \%$ dan $100 \%$ meningkatkan hasil gabah yang nyata lebih tinggi $\left(1,05 \mathrm{~kg} / \mathrm{m}^{3}\right.$ dan $\left.1,13 \mathrm{~kg} / \mathrm{m}^{3}\right)$ dibandingkan dengan perlakuan kompos tanpa pupuk NPK $\left(0,83 \mathrm{~kg} / \mathrm{m}^{3}\right)$. Demikian juga hasil penelitian Amrah (2008), bahwa perlakuan kombinasi jerami +1 dosis pupuk anorganik memberikan hasil gabah tertinggi dibandingkan dengan kontrol (tanpa jerami, tanpa pupuk anorganik).

\section{KESIMPULAN DAN SARAN}

\section{Kesimpulan}

Dari hasil penelitian dapat disimpulkan bahwa pemberian pupuk organik berpengaruh nyata terhadap tinggi tanaman, jumlah anakan, jumlah gabah per malai, bobot 1000 butir, dan hasil gabah kering panen (GKP). Hasil GKP tertinggi dicapai oleh perlakuan pupuk organik jerami dan pupuk organik tanaman legum yang dikombinasikan dengan $40 \% \mathrm{NPK}$, dengan nilai masingmasing 9,03 tha- $^{-1}$ dan 8,62 ton ha-1.

\section{Saran}

Berdasarkan hasil penelitian disarankan kepada petani untuk memanfaatkan limbah pertanaman, seperti jerami padi dan jenis-jenis tanaman leguminosa sebagai sumber pupuk organik dalam budidaya padi sawah dengan metode SRI.

\section{DAFTAR PUSTAKA}

Amrah, M. L. 2008. Pengaruh Manajemen Jerami Terhadap Pertumbuhan dan Produksi Padi Sawah (Oryza sativa L.). Skripsi S1. Prodi Agronomi, Fakultas Pertanian IPB. http://repository.ipb.ac.id. Diakses 2 Nopember 2015.

Anonim. 2009. Budidaya Padi Metode SRI : Pertanian Padi Sawah Ramah Lingkungan Berkelanjutan. http://organikbali.com. Diakses tanggal 8 Januari 2014.

Anugrah, I.S., Sumedi, dan I Putu Wardhana. 2008. Gagasan dan Implementasi System of Rice Intensification (SRI) Dalam Kegiatan 
Budidaya Padi Ekologis (BPE). Analisis Kebijakan Pertanian Vol.16 No.1 Maret 2008 : 75-99.

Barus, J. 2011. Uji Efektifitas Kompos Jerami dan Pupuk NPK Terhadap Hasil padi. J. Agrivigor 10(3): 247-252, Mei-Agustus 2011, ISSN 1412-2286. http://portal garuda.orgipi29643.pdf. Diakses tanggal 3 Nopember 2015.

Dinas Pertanian Tanaman Pangan. 2006. Pertanian Organik: Mengapa Harus SRI?. Kerjasama Dinas Pertanian Tanaman Pangan Kabupaten Tasikmalaya dengan KTNA Kabupaten Tasikmalaya.

Las, I. 2009. Revolusi Hijau Lestari untuk Ketahanan Pangan ke Depan : Salah satu isu penting dalam Hight Level Regional Policy Dialogue on The Food-Fuel Crisis and Climate Change: Reshaping the Development Agenda' yang digelar oleh Economic and Social Commision for ASIA and the Pasific (ESCAP) dan Pemerintah Indonesia di Bali.Tabloid Sinar Tani, 14 Februari 2009.

Muhammad Nizar, H. 2011. Pengaruh Beberapa Jenis Bahan Organik Terhadap Pertumbuhan dan Hasil Tanaman Padi (Oryza sativa L.) Metode SRI (System of Rice Intensification). Skripsi S1. Fakultas Pertanian Universitas Andalas, Padang. http://repository.unand.ac.id. Diakses tanggal 6 Nopember 2015.

Mulyadi, A. 2008. Karakteristik Kompos dari Bahan Tanaman Kaliandra, Jerami Padi, dan Sampah Sayuran. Skripsi S1. Program Studi IImu Tanah. IPB. Bogor. http://repository.ipb.ac.id. Diakses 1 Februari 2016
Ningtias, N. E. M. dan T. Suharjanto. 2012. Sistem Intensifikasi Padi Aerob Terkendali Berbasis Organik di Kelurahan Tunggul Wulung, Kota Malang. Agrika, Vol.6, No.1: 13-21. http://.widyagama.ac.id.pdf. Diakses tanggal 12 Nopember 2015.

Nizar, M. 2011. Pengaruh Beberapa Jenis Bahan Organik Terhadap Pertumbuhan dan Hasil. http://repository.usu.id. Diakses tanggal 2 Januari 2016.

Paulus, J. M., J. E. X. Rogi, and J. H. Senduk. 2014. The Effect of Some Types of Green Manure Application toward the Growth and Production of Rice (Oryza sativa L.). International Journal of Applied Envirinmental Sciences Vol.9, No. 5 : 2579-2586.

Sampoerna. 2009. Teknik dan Budidaya Penanaman Padi System of Rice Intensification (SRI). Pusat Pelatihan Kewirausahaan Sampoerna. Desa Gunting Kec. Sukorejo Kab. Pasuruan. Sampoerna.indoSampoernaManual09.pdf. Diakses tanggal 2 Desember 2014.

Sutanto, R. 2002. Penerapan Pertanian Organik : Pemasyarakatan dan Pengembangannya. Kanisius. Yogyakarta.

Veco Indonesia. 2007. Menembus Batas Kebuntuan Produksi: Cara SRI Dalam Budidaya Padi. indovecoManual07.pdf. Diakses tanggal 2 Desember $2014 .$.

Kaya, E. 2013. Pengaruh Kompos Jerami dan Pupuk NPK Terhadap N-Tersedia Tanah, Serapan N, Pertumbuhan dan Hasil Padi Sawah (Oryza sativa L.). Agrologia Vol. 2 (1) : 43-50. 